\title{
Contribution of arbuscular mycorrhizas to biological protection of micropropagated pineapple (Ananas comosus (L.) Merr) against Phytophthora cinnamomi Rands
}

\author{
Jean-Philippe Guillemin, Silvio Gianinazzi, Vivienne Gianinazzi-Pearson and Jean Marchal
}

Guillemin, J.P.', Gianinazzi, S.', Gianinazzi-Pearson, V.' \& Marchal, J. ${ }^{2} 1994$. Contribution of endomycorrhizas to biological protection of micropropagated pineapple (Ananas comosus (L.) Merr) against Phytophthora cinnamomi Rands. Agricultural Science in Finland 3: 241-251. (' Laboratoire de Phytoparasitologie, INRA-CNRS, Station de Génétique et d'Amélioration des Plantes, INRA, BV 1540, 21034 Dijon Cedex, France and ${ }^{2}$ Laboratoire de Physiologie et Biochimie, CIRAD, FLHOR, Avenue du Val de Montferrand, BP 5035, 34032 Montpellier Cedex 01, France.)

Phytophthora cinnamomi Rands causes root rot of pineapple (Ananas comosus (L.) Merr.) and the development of this disease is harmful for fruit production. Micropropagated plants of two varieties, Queen Tahiti and Smooth Cayenne (clone CY0), were inoculated at transplanting from axenic conditions with an arbuscular mycorrhizal fungus to evaluate the importance of endomycorrhiza development for biological protection against $P$. cinnamomi. Growth and mineral nutrition of endomycorrhizal plants were not affected by different inoculum levels of $P$. cinnamomi, whilst they were reduced for non-mycorrhizal plants. Root/shoot ratio of endomycorrhizal plants was lower than that of non-mycorrhizal plants, and the pathogen did not modify this effect except at highest inoculum levels of $P$. cinnamomi. Endomycorrhizal colonization was not altered by the pathogen; however symbiotic functioning was reduced by the highest concentration of inoculum of P.cinnamomi. Endomycorrhization is an interesting biotechnology for the production of micropropagated pineapple.

Key words: arbuscular endomycorrhizal infection, bioprotection agent, pathogen fungus, pineapple microplant, plant growth

\section{Introduction}

In soil, plant roots develop in the presence of micro-organisms, some of which can have a positive (e.g. arbuscular mycorrhizal fungi (AMF)) or negative (e.g. pathogen fungi) impact on plant growth. Root rot of pineapple (Ananas comosus (L.) Merr.), caused by the soilborne fungus Phytophthora cinnamomi Rands, is a major problem in pineapple production (MenrLICH 1936). This pathogen damages root systems, negatively in- fluences shoot development (MEHRLICH 1934) causes the production of fruits without commercial interest (Py et al. 1984) and is able to devastate plantations (ANDERSON 1951). The disease is presently controlled by chemical applications (Pegg 1977, Rochbach and Schenck 1985) and/ or by modifying the soil environment before planting (drainage, $\mathrm{pH}$ reduction).

Several reports have indicated the bioprotective effect of endomycorrhiza formation against pathogens (GianinazZI et al. 1982, PAUlitz and 
LINDERMAN 1991). However results are contradictory for P.cinnamomi. Whilst an important decrease in root rot disease was observed for endomycorrhizal plants of Chamaecyparis lawsoniana L. (BÄRTSCHI et al. 1981), the impact of the disease was not modified by endomycorrhization of avocado (MATARÉ and HATTING 1978) or citrus (DAvis et al. 1978). The aim of this work was to evaluate the success of AMF as biological control agents against damage by P.cinnamomi in pineapple plant production.

\section{Material and methods}

Two micropropagated pineapple varieties, Queen Tahiti and Smooth Cayenne (clone CY0), were used. Experiments were carried out under simulated tropical conditions $\left(300 \mu \mathrm{E} \mathrm{s}^{-1} \mathrm{~m}^{-2}, 29-25^{\circ} \mathrm{C}\right.$, $12 \mathrm{~h} / 12 \mathrm{~h}, 70-90 \%$ relative humidity). Micropropagated plants were inoculated at transplanting from axenic conditions with root fragments of Tephrosia ehlenbergiana infected by an isolate of Glomus sp. (LPA21). Inoculation was performed in seed trays containing a mix $(1: 1, \mathrm{v}: \mathrm{v})$ of $\gamma$-irradiated (10kGy) acid soil (Marlins, pH 5.0) and steamsterilized gravel (GuILlemin et al. 1991). Four weeks later, micropropagated plants were individually outplanted to pots containing $400 \mathrm{~g}$ of the soil-gravel mix. Plant were watered daily with distilled water and twice weekly $20 \mathrm{ml}$ of Hoagland no. 2 nutrient solution (HoAGLAND and ARNON 1950) without phosphate was supplied.

P.cinnamomi (strain 50, Laboratoire de Pathologie, CIRAD, FLHOR, Montpellier, France) was grown in $30 \mathrm{ml}$ of liquid culture at $25^{\circ} \mathrm{C}$ (LOUvEL 1975). After one week, the macerated P.cinnamomi culture was diluted in water from 10-fold to 10000 -fold (levels 4 to 1). After pre-inoculation with AMF, $30 \mathrm{ml}$ inoculum was applied to each plant at outplanting to pots, or one month later. For the later application, only two dilution levels (1: 10 (level 4) and 1: 100 (level 3)) were used.

Plant growth was evaluated by leaf area (CHAUVEL 1991), shoot and root fresh weight and shoot dry weight. N, P, K, Ca and Mg contents of shoots were analysed (WARNER and JONES 1967, Comité
Inter Instituts pour le diagnostic foliaire 1968, 1972). Endomycorrhizal colonization was evaluated by the Trouvelot et al. (1986) method (intensity of infection in the root cortex (M\%) and arbuscular frequency in the root cortex (A\%)) after clearing and staining with trypan blue (PHILIPPS and HAYMAN 1970) and after staining for succinate dehydrogenase (SDH) (living) (SMith and GianinazZi-PEARSON 1990) or alkaline phosphatase (ALP) (functional) (TISSERANT et al. 1993) activities.

Each treatment consisted of 5 replicates and all data was analysed statistically by NewmanKeuls tests.

\section{Results}

\section{Development of the endomycorrhizal infection}

The endomycorrhizal colonization was well developed in roots of both pineapple varieties. Evaluations of infection intensity (M\%) were between $83 \%$ and $91 \%$ after non vital staining with trypan blue (Fig. 1). Values of M\% estimated after staining for SDH and ALP activities, to evaluate living and functional infection respectively, were lower, fluctuating between $48 \%$ and $63 \%$ for the former, and between $27 \%$ and $38 \%$ for the latter (Fig. 1A, 1B, 2A, 2B). P.cinnamomi did not significantly affect infection intensity $(\mathrm{M} \%)$ for either inoculation time, that is at transplanting to pots (Fig. 1A, 2A) or one month later (Fig. 1B, 2B).

Arbuscule frequency (A\%) estimated by trypan blue and ALP staining was significantly reduced for the Queen Tahiti variety in presence of the highest inoculum level of $P$. cinnamomi at outplanting to pots (Fig. 1C). For the Smooth Cayenne variety, reduction of A\% was observed only for ALP staining and after inoculation of highest concentration of the pathogen at outplanting to pots (Fig. 2C).

\section{Development of $P$. cinnamomi infection}

No necroses were observed on roots of non-mycorrhizal and endomycorrhizal plants infected by 

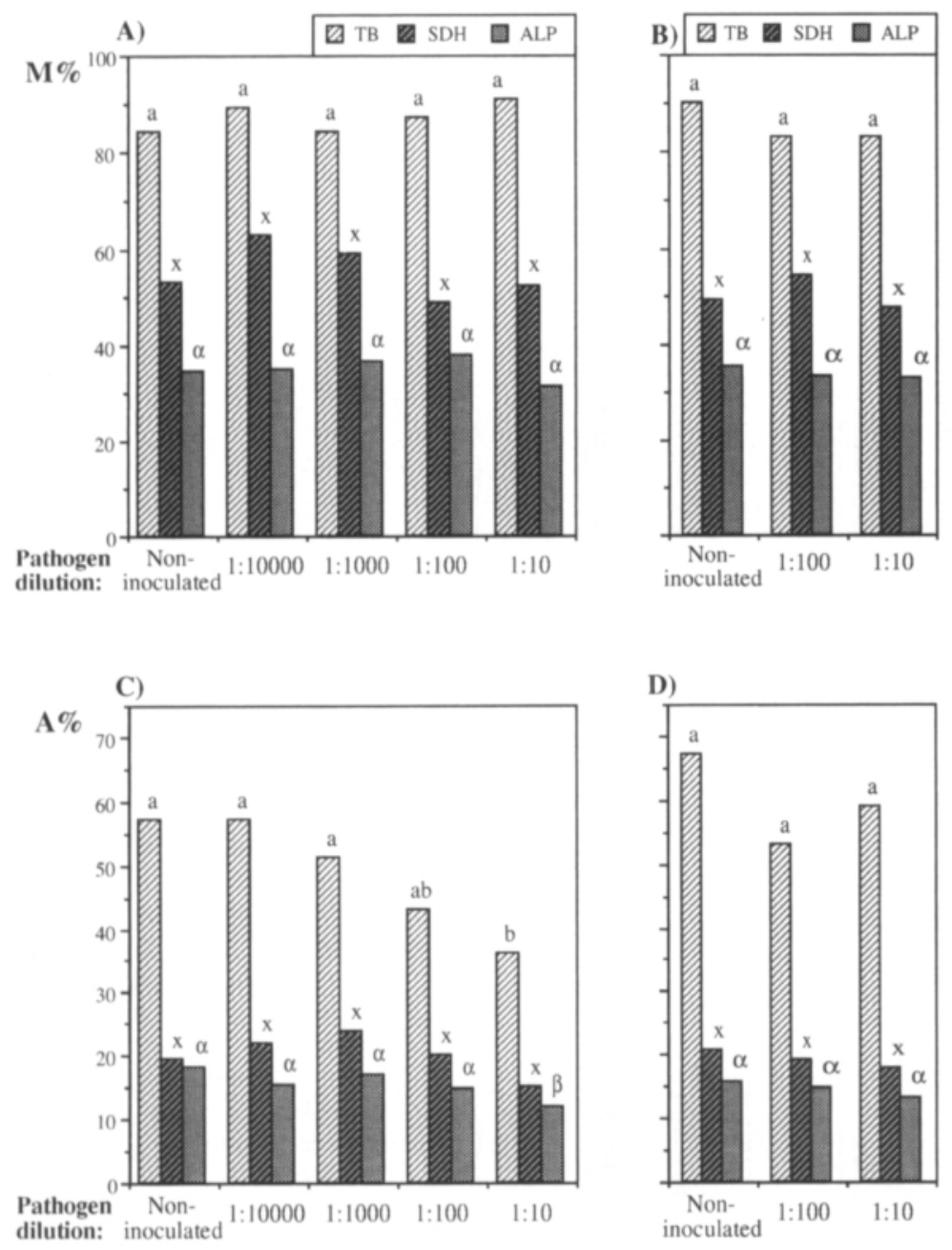

Fig. 1. Intensity of infection (M\%) (A and $\mathbf{B})$ and arbuscular frequency $(\mathbf{A} \%)(\mathbf{C}$ and $\mathbf{D})$ observed after trypan blue (TB), succinate dehydrogenase $(\mathrm{SDH})$ and alkaline phosphatase (ALP) staining of roots of endomycorrhizal Queen Tahiti variety of pineapple inoculated with $P$. cinnamomi at different dilutions at outplanting to pots (A and $\mathbf{C}$ ) and one month later (B and D). Values for each staining followed by different letters are significantly different $(\mathrm{p}=0.05)$.

P. cinnamomi at any concentrations of the pathogen inoculum.

\section{Plant growth}

The important development of the AMF in roots of both pineapple varieties was reflected in the better growth of endomycorrhizal plants, with or without $P$. cinnamomi (Tables 1, 2, 3, 4).

\section{Effect of $P$. cinnamomi at outplanting to pots}

$P$. cinnamomi significantly decreased shoot growth of non-mycorrhizal plants of the Queen Tahiti variety at all dilutions whilst such a negative effect was only observed for endomycorrhizal plants at the highest inoculum level of the pathogen (Table 1). All concentrations of $P$. cinnamomi significantly decreased root growth of non-mycorrhizal plants whilst root growth of endomycorrhizal plants was only negatively influenced by the two higher levels of pathogen inoculum (Table 1). Shoot and root growth of endomycorrhizal plants, whether infected or not by $P$. cinnamo$m i$, was always greater than that of non-mycorrhizal plants.

Plants of the Smooth Cayenne variety tolerat- 

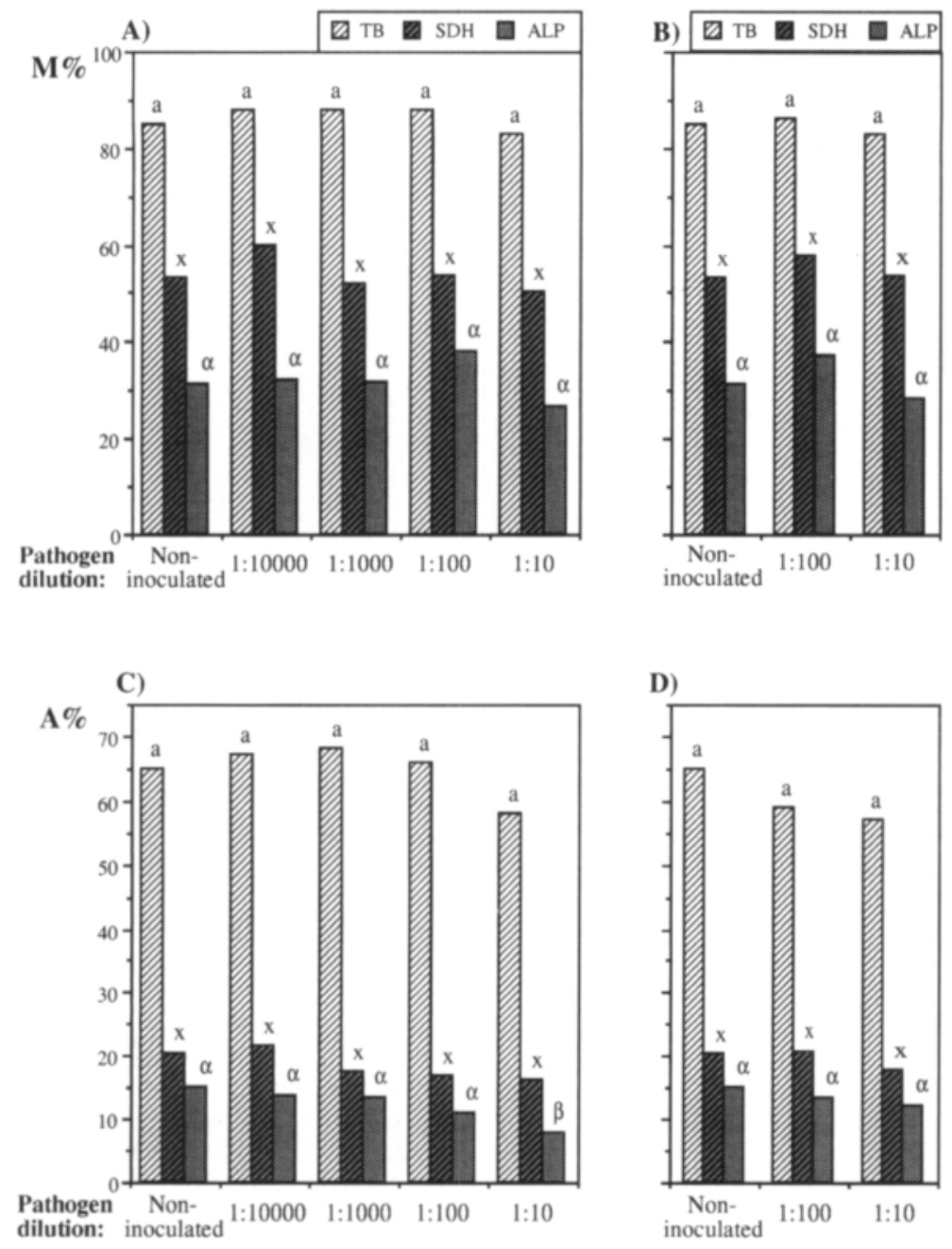

Fig. 2. Intensity of infection (M\%) (A and B) and arbuscular frequency $(\mathbf{A} \%)(\mathbf{C}$ and $\mathbf{D})$ observed after trypan blue (TB), succinate dehydrogenase $(\mathrm{SDH})$ and alkaline phosphatase (ALP) staining of roots of endomycorrhizal Smooth Cayenne variety of pineapple inoculated with $P$. cinnamomi at different dilutions at outplanting to pots ( $\mathbf{A}$ and $\mathbf{C}$ ) and one month after later (B and D). Values for each staining followed by different letters are significantly different $(p=0.05)$.

ed $P$. cinnamomi better. Only the inoculum dilutions of 1:100 and 1:10 affected shoot growth of non-mycorrhizal plants. For endomycorrhizal plants, shoot growth was not significantly affected by the pathogen at any concentration (Table 2). However, root growth of endomycorrhizal plants was altered by higher levels of pathogen inoculum, but values were always greater than those of non-mycorrhizal plants, with or without the pathogen.

In these experiments, root/shoot ratios (R/A) of endomycorrhizal plants were always lower than those of non-mycorrhizal plants for both pineap- ple varieties except for endomycorrhizal plants of the Queen Tahiti variety in presence of the highest level of P. cinnamomi inoculum (Fig. 3A, 3C).

In the absence of $P$. cinnamomi, endomycorrhiza formation improved shoot mineral contents of the Queen Tahiti variety (Table 5). Pathogen inoculation caused a reduction in the $\mathrm{P}$ concentration of non-mycorrhizal plants. Decreases in $\mathrm{Ca}$ and $\mathrm{Mg}$ nutrition were less important for P. cinnamomi-inoculated endomycorrhizal plants. However, $\mathrm{N}$ and $\mathrm{K}$ concentrations tended to increase in the presence of $P$. cinnamomi in all plants (Table 5). 
Table 1. Leaf area $\left(\mathrm{cm}^{2}\right)$, shoot $(\mathrm{g})$ and root $(\mathrm{g})$ fresh mass and shoot dry $(\mathrm{g})$ mass of endomycorrhizal (M) and nonmycorrhizal (NM) Queen Tahiti variety of pineapple, inoculated at outplanting to pots with Phytophthora cinnamomi at different dilutions.

\begin{tabular}{llcccc}
\hline $\begin{array}{l}\text { Pathogen } \\
\text { dilution }\end{array}$ & Leaf area & $\begin{array}{c}\text { Shoot fresh } \\
\text { mass }\end{array}$ & $\begin{array}{c}\text { Root fresh } \\
\text { mass }\end{array}$ & $\begin{array}{c}\text { Shoot dry } \\
\text { mass }\end{array}$ \\
\hline Non-inoculated & $\mathrm{NM}$ & $312.4 \mathrm{~b}$ & $24.82 \mathrm{~b}$ & $2.52 \mathrm{~b}$ & $2.58 \mathrm{~b}$ \\
& $\mathrm{M}$ & $482.9 \mathrm{a}$ & $37.52 \mathrm{a}$ & $3.52 \mathrm{a}$ & $3.99 \mathrm{a}$ \\
$1: 10000$ & $\mathrm{NM}$ & $221.5 \mathrm{c}$ & $16.84 \mathrm{c}$ & $1.78 \mathrm{c}$ & $1.74 \mathrm{c}$ \\
& $\mathrm{M}$ & $484.1 \mathrm{a}$ & $33.80 \mathrm{a}$ & $3.22 \mathrm{ab}$ & $3.61 \mathrm{a}$ \\
$1: 1000$ & $\mathrm{NM}$ & $165.9 \mathrm{c}$ & $13.23 \mathrm{c}$ & $1.45 \mathrm{c}$ & $1.43 \mathrm{c}$ \\
& $\mathrm{M}$ & $437.1 \mathrm{a}$ & $32.65 \mathrm{a}$ & $3.09 \mathrm{ab}$ & $3.30 \mathrm{a}$ \\
$1: 100$ & $\mathrm{NM}$ & $223.3 \mathrm{c}$ & $16.62 \mathrm{c}$ & $1.80 \mathrm{c}$ & $1.72 \mathrm{c}$ \\
& $\mathrm{M}$ & $463.5 \mathrm{a}$ & $33.66 \mathrm{a}$ & $2.83 \mathrm{~b}$ & $3.51 \mathrm{a}$ \\
$1: 10$ & $\mathrm{NM}$ & $240.9 \mathrm{c}$ & $17.75 \mathrm{c}$ & $1.63 \mathrm{c}$ & $1.85 \mathrm{c}$ \\
& $\mathrm{M}$ & $344.0 \mathrm{~b}$ & $26.07 \mathrm{~b}$ & $2.85 \mathrm{~b}$ & $2.43 \mathrm{~b}$ \\
\hline
\end{tabular}

Values in a column followed by different letters are significantly different $(p=0.05)$

Table 2. Leaf area $\left(\mathrm{cm}^{2}\right)$, shoot $(\mathrm{g})$ and root $(\mathrm{g})$ fresh mass and shoot dry $(\mathrm{g})$ mass of endomycorrhizal (M) and nonmycorrhizal (NM) Smooth Cayenne variety of pineapple, inoculated at outplanting to pots with Phytophthora cinnamomi at different dilutions.

\begin{tabular}{llcccc}
\hline $\begin{array}{l}\text { Pathogen } \\
\text { dilution }\end{array}$ & Leaf area & $\begin{array}{c}\text { Shoot fresh } \\
\text { mass }\end{array}$ & $\begin{array}{c}\text { Root fresh } \\
\text { mass }\end{array}$ & $\begin{array}{c}\text { Shoot dry } \\
\text { mass }\end{array}$ \\
\hline Non-inoculated & NM & $299.7 \mathrm{~b}$ & $23.25 \mathrm{~b}$ & $2.63 \mathrm{c}$ & $2.88 \mathrm{~b}$ \\
& $\mathrm{M}$ & $640.9 \mathrm{a}$ & $54.87 \mathrm{a}$ & $5.48 \mathrm{a}$ & $5.02 \mathrm{a}$ \\
$1: 10000$ & $\mathrm{NM}$ & $285.5 \mathrm{~b}$ & $22.37 \mathrm{~b}$ & $2.42 \mathrm{c}$ & $2.31 \mathrm{~b}$ \\
& $\mathrm{M}$ & $527.9 \mathrm{a}$ & $46.14 \mathrm{a}$ & $4.16 \mathrm{ab}$ & $4.10 \mathrm{a}$ \\
$1: 1000$ & $\mathrm{NM}$ & $373.9 \mathrm{~b}$ & $23.45 \mathrm{~b}$ & $2.52 \mathrm{c}$ & $2.43 \mathrm{~b}$ \\
& $\mathrm{M}$ & $544.3 \mathrm{a}$ & $45.44 \mathrm{a}$ & $4.35 \mathrm{ab}$ & $4.36 \mathrm{a}$ \\
$1: 100$ & $\mathrm{NM}$ & $241.0 \mathrm{~b}$ & $18.27 \mathrm{c}$ & $2.03 \mathrm{~cd}$ & $1.73 \mathrm{c}$ \\
& $\mathrm{M}$ & $479.2 \mathrm{a}$ & $39.05 \mathrm{ab}$ & $3.64 \mathrm{~b}$ & $3.43 \mathrm{ab}$ \\
$1: 10$ & $\mathrm{NM}$ & $166.6 \mathrm{c}$ & $12.65 \mathrm{c}$ & $1.74 \mathrm{~d}$ & $1.24 \mathrm{c}$ \\
& $\mathrm{M}$ & $502.2 \mathrm{a}$ & $39.02 \mathrm{ab}$ & $3.86 \mathrm{~b}$ & $3.71 \mathrm{a}$ \\
\hline
\end{tabular}

Values in a column followed by different letters are significantly different $(p=0.05)$

Table 3. Leaf area $\left(\mathrm{cm}^{2}\right)$, shoot $(\mathrm{g})$ and root $(\mathrm{g})$ fresh mass and shoot dry $(\mathrm{g})$ mass of endomycorrhizal (M) and nonmycorrhizal (NM) Queen Tahiti variety of pineapple, inoculated one month after outplanting to pots with Phytophthora cinnamomi at different dilutions.

\begin{tabular}{llcccc}
\hline $\begin{array}{l}\text { Pathogen } \\
\text { dilution }\end{array}$ & Leaf area & $\begin{array}{c}\text { Shoot fresh } \\
\text { mass }\end{array}$ & $\begin{array}{c}\text { Root fresh } \\
\text { mass }\end{array}$ & $\begin{array}{c}\text { Shoot dry } \\
\text { mass }\end{array}$ \\
\hline Non-inoculated & $\mathrm{NM}$ & $278.1 \mathrm{~b}$ & $22.14 \mathrm{c}$ & $2.49 \mathrm{c}$ & $2.09 \mathrm{~b}$ \\
& $\mathrm{M}$ & $637.0 \mathrm{a}$ & $49.03 \mathrm{a}$ & $5.04 \mathrm{a}$ & $4.64 \mathrm{a}$ \\
$1: 100$ & $\mathrm{NM}$ & $272.6 \mathrm{~b}$ & $21.86 \mathrm{c}$ & $2.29 \mathrm{c}$ & $2.09 \mathrm{~b}$ \\
& $\mathrm{M}$ & $590.9 \mathrm{a}$ & $40.14 \mathrm{ab}$ & $3.77 \mathrm{~b}$ & $4.08 \mathrm{a}$ \\
$1: 10$ & $\mathrm{NM}$ & $230.2 \mathrm{c}$ & $16.99 \mathrm{~d}$ & $1.49 \mathrm{~d}$ & $1.59 \mathrm{c}$ \\
& $\mathrm{M}$ & $549.8 \mathrm{a}$ & $38.14 \mathrm{ab}$ & $4.15 \mathrm{ab}$ & $3.94 \mathrm{a}$ \\
\hline
\end{tabular}

Values in a column followed by different letters are significantly different $(p=0.05)$ 
Table 4. Leaf area $\left(\mathrm{cm}^{2}\right)$, shoot $(\mathrm{g})$ and root $(\mathrm{g})$ fresh mass and shoot dry $(\mathrm{g})$ mass of endomycorrhizal (M) and nonmycorrhizal (NM) Smooth Cayenne variety of pineapple, inoculated one month after outplanting with Phytophthora cinnamomi at different dilutions.

\begin{tabular}{llcccc}
\hline $\begin{array}{l}\text { Pathogen } \\
\text { dilution }\end{array}$ & Leaf area & $\begin{array}{c}\text { Shoot fresh } \\
\text { mass }\end{array}$ & $\begin{array}{c}\text { Root fresh } \\
\text { mass }\end{array}$ & $\begin{array}{c}\text { Shoot dry } \\
\text { mass }\end{array}$ \\
\hline Non-inoculated & $\mathrm{NM}$ & $299.7 \mathrm{~b}$ & $23.25 \mathrm{~b}$ & $2.63 \mathrm{~b}$ & $2.88 \mathrm{~b}$ \\
& $\mathrm{M}$ & $640.9 \mathrm{a}$ & $54.87 \mathrm{a}$ & $5.48 \mathrm{a}$ & $5.02 \mathrm{a}$ \\
$1: 100$ & $\mathrm{NM}$ & $244.2 \mathrm{~b}$ & $20.07 \mathrm{~b}$ & $2.54 \mathrm{~b}$ & $2.02 \mathrm{~b}$ \\
& $\mathrm{M}$ & $540.6 \mathrm{a}$ & $46.16 \mathrm{a}$ & $4.40 \mathrm{a}$ & $4.44 \mathrm{a}$ \\
$1: 10$ & $\mathrm{NM}$ & $287.7 \mathrm{~b}$ & $23.06 \mathrm{~b}$ & $2.44 \mathrm{~b}$ & $2.25 \mathrm{~b}$ \\
& $\mathrm{M}$ & $523.1 \mathrm{a}$ & $44.22 \mathrm{a}$ & $4.18 \mathrm{a}$ & $4.01 \mathrm{a}$ \\
\hline
\end{tabular}

Values in a column followed by different letters are significantly different $(\mathrm{p}=0.05)$
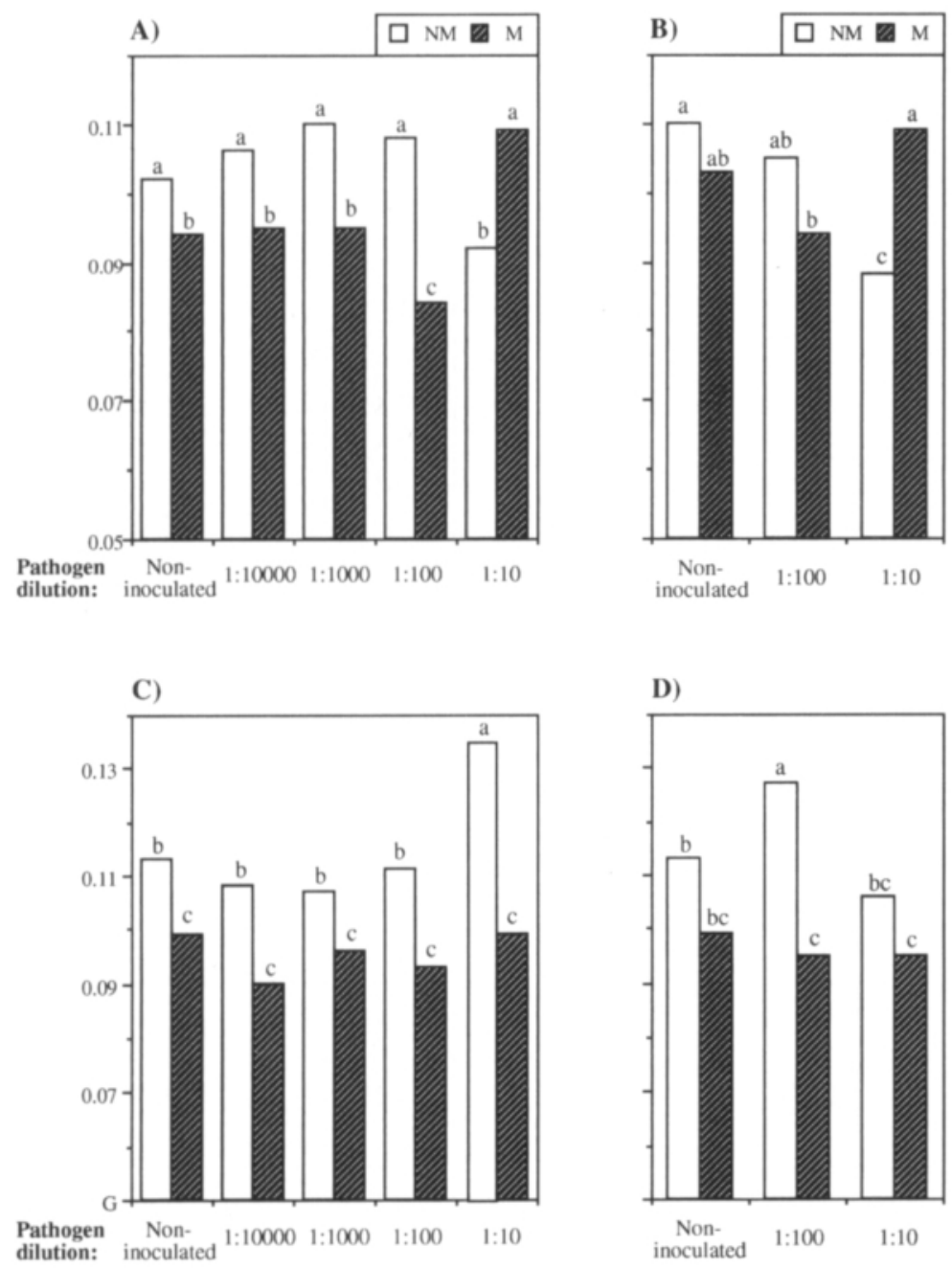

Fig. 3. Root/shoot ratios of nonmycorrhizal (NM) and endomycorrhizal (M) Queen Tahiti (A, B) and Smooth Cayenne $(\mathbf{C}, \mathbf{D})$ varieties of pineapple inoculated with Phytophthora cinnamomi at different dilutions: $\mathbf{A}, \mathbf{C})$ at outplanting to pots and $\mathbf{B}, \mathbf{D}$ ) one month later. Values followed by different letters are significantly different $(\mathrm{p}=0.05)$. 
Table 5. Mineral concentration (\% of dry mass) of shoot of nonmycorrhizal (NM) and endomycorrhizal (M) Queen Tahiti variety of pineapple inoculated with Phytophthora cinnamomi at different dilutions at outplanting to pots

\begin{tabular}{llccccc}
\hline Pathogen dilution & & $\mathrm{N}$ & $\mathrm{P}$ & $\mathrm{K}$ & $\mathrm{Ca}$ & $\mathrm{Mg}$ \\
\hline Non-inoculated & $\mathrm{NM}$ & 1.72 & 0.10 & 3.83 & 0.83 & 0.33 \\
& $\mathrm{M}$ & 1.83 & 0.12 & 3.87 & 0.91 & 0.36 \\
$1: 10000$ & $\mathrm{NM}$ & 1.82 & 0.07 & 4.40 & 0.64 & 0.27 \\
& $\mathrm{M}$ & 1.87 & 0.14 & 4.03 & 0.84 & 0.36 \\
$1: 1000$ & $\mathrm{NM}$ & 1.80 & 0.06 & 4.47 & 0.68 & 0.27 \\
& $\mathrm{M}$ & 1.90 & 0.11 & 4.03 & 0.76 & 0.31 \\
$1: 100$ & $\mathrm{NM}$ & 2.45 & 0.08 & 4.62 & 0.74 & 0.28 \\
& $\mathrm{M}$ & 1.89 & 0.11 & 4.10 & 0.83 & 0.34 \\
$1: 10$ & $\mathrm{NM}$ & 1.90 & 0.09 & 4.40 & 0.82 & 0.32 \\
& $\mathrm{M}$ & 2.22 & 0.14 & 4.42 & 0.90 & 0.36 \\
\hline
\end{tabular}

Table 6. Mineral concentration (\% of dry mass) of shoot of nonmycorrhizal (NM) and endomycorrhizal (M) Smooth Cayenne variety of pineapple inoculated with Phytophthora cinnamomi at different dilutions at outplanting to pots

\begin{tabular}{llccccc}
\hline Pathogen dilution & & $\mathrm{N}$ & $\mathrm{P}$ & $\mathrm{K}$ & $\mathrm{Ca}$ & $\mathrm{Mg}$ \\
\hline Non-inoculated & $\mathrm{NM}$ & 2.03 & 0.13 & 4.46 & 1.05 & 0.35 \\
& $\mathrm{M}$ & 1.99 & 0.13 & 4.07 & 1.17 & 0.34 \\
$1: 10000$ & $\mathrm{NM}$ & 2.21 & 0.11 & 4.68 & 1.11 & 0.32 \\
& $\mathrm{M}$ & 1.99 & 0.17 & 3.81 & 1.19 & 0.35 \\
$1: 1000$ & $\mathrm{NM}$ & 2.04 & 0.11 & 3.90 & 1.12 & 0.34 \\
& $\mathrm{M}$ & 2.02 & 0.15 & 4.14 & 1.23 & 0.35 \\
$1: 100$ & $\mathrm{NM}$ & 1.95 & 0.09 & 4.20 & 1.05 & 0.33 \\
& $\mathrm{M}$ & 1.96 & 0.17 & 3.94 & 1.23 & 0.38 \\
$1: 10$ & $\mathrm{NM}$ & 2.07 & 0.08 & 4.71 & 1.07 & 0.33 \\
& $\mathrm{M}$ & 1.99 & 0.17 & 3.68 & 1.18 & 0.37 \\
\hline
\end{tabular}

For the Smooth Cayenne variety, positive effects of endomycorrhiza on $\mathrm{P}, \mathrm{Ca}$ and $\mathrm{Mg}$ nutrition was more important in presence of the pathogen (Table 6). $\mathrm{N}$ and $\mathrm{K}$ concentrations were not modified by P.cinnamomi inoculation and were generally slightly lower for endomycorrhizal plants (Table 6).

\section{Effect of $P$. cinnamomi one month after outplanting to pots}

In contrast to non-mycorrhizal plants, shoot growth of endomycorrhizal plants of the Queen
Tahiti variety was not altered by P.cinnamomi inoculation (Table 3). However, the root growth of both endomycorrhizal or non-mycorrhizal plants of this variety was reduced by the pathogen (Table 3). P.cinnamomi did not affect shoot or root growth of the Smooth Cayenne variety (Table 4).

As could be expected, root/shoot ratios were lower in endomycorrhizal plants, with the exception of the Queen Tahiti variety in presence of the highest level of $P$. cinnamomi inoculum (Fig. 3B, 3D).

Endomycorrhization increased $\mathrm{P}, \mathrm{Ca}$ and $\mathrm{Mg}$ 
Table 7. Mineral concentration (\% of dry mass) of shoot of nonmycorrhizal (NM) and endomycorrhizal (M) Queen Tahiti variety of pineapple inoculated with Phytophthora cinnamomi at different dilutions one month after outplanting to pots

\begin{tabular}{llccccc}
\hline Pathogen dilution & & $\mathrm{N}$ & $\mathrm{P}$ & $\mathrm{K}$ & $\mathrm{Ca}$ & $\mathrm{Mg}$ \\
\hline Non-inoculated & $\mathrm{NM}$ & 2.21 & 0.09 & 5.12 & 0.80 & 0.27 \\
& $\mathrm{M}$ & 1.77 & 0.15 & 3.54 & 1.03 & 0.36 \\
$1: 100$ & $\mathrm{NM}$ & 1.97 & 0.08 & 5.04 & 0.73 & 0.28 \\
& $\mathrm{M}$ & 1.63 & 0.14 & 3.57 & 0.96 & 0.38 \\
$1: 10$ & $\mathrm{NM}$ & 2.33 & 0.11 & 5.11 & 0.84 & 0.32 \\
& $\mathrm{M}$ & 1.75 & 0.15 & 3.95 & 0.99 & 0.37 \\
\hline
\end{tabular}

Table 8. Mineral concentration (\% of dry mass) of shoot of nonmycorrhizal (NM) and endomycorrhizal (M) Smooth Cayenne variety of pineapple inoculated with Phytophthora cinnamomi at different dilutions one month after outplanting to pots

\begin{tabular}{llccccc}
\hline Pathogen dilution & & $\mathrm{N}$ & $\mathrm{P}$ & $\mathrm{K}$ & $\mathrm{Ca}$ & $\mathrm{Mg}$ \\
\hline Non-inoculated & $\mathrm{NM}$ & 2.03 & 0.13 & 4.46 & 1.05 & 0.35 \\
& $\mathrm{M}$ & 1.99 & 0.13 & 4.07 & 1.17 & 0.34 \\
$1: 100$ & $\mathrm{NM}$ & 2.18 & 0.12 & 4.87 & 1.02 & 0.33 \\
& $\mathrm{M}$ & 2.27 & 0.15 & 4.28 & 1.24 & 0.35 \\
$1: 10$ & $\mathrm{NM}$ & 2.19 & 0.08 & 4.66 & 1.18 & 0.33 \\
& $\mathrm{M}$ & 1.94 & 0.17 & 3.89 & 1.21 & 0.36 \\
\hline
\end{tabular}

nutrition of the Queen Tahiti variety with and without $P$. cinnamomi (Table 7). However, $\mathrm{N}$ concentration of endomycorrhizal plants was less (phenomenon of dilution). The effect of the symbiotic fungus on $\mathrm{P}$ nutrition was more important in presence of the pathogen for the Smooth Cayenne variety (Table 8). For both varieties, $\mathrm{N}$ and $\mathrm{K}$ contents were lower in endomycorrhizal plants and $P$. cinnamomi inoculation did not modify this effect (Tables 7, 8).

\section{Discussion}

Experiments with both pineapple varieties showed that the endomycorrhizal effect on plant growth was not influenced by $P$. cinnamomi, except for the Queen Tahiti variety in the presence of the highest concentration of pathogen, when patho- gen inoculation was carried out at outplanting to pots. The negative effect of $P$. cinnamomi on nonmycorrhizal plants was likewise important for the Queen Tahiti variety when inoculation was performed at outplanting to pots. Pathogen inoculation did not alter endomycorrhizal colonization of this variety roots but the highest concentration of inoculum depressed fungal activity (arbuscule formation, ALP activity and endomycorrhizal effect). The reduction in endomycorrhizal plant growth could be explained by a less efficient endomycorrhizal symbiosis in the presence of $P$. cinnamomi.

The influence of the pathogen depends on several factors. Although root necroses were not observed both varieties of micropropagated pineapple showed varying susceptibility to negative effects of $P$. cinnamomi. Better shoot growth of the Smooth Cayenne variety following colonization 
by AMF was less affected by $P$. cinnamomi than that of the Queen Tahiti variety. The level of pathogen inoculum influenced plant growth in a similar way to that reported by DAVIS and MENGE (1981) for citrus, with growth of endomycorrhizal pineapple being decreased at higher levels of $P$. cinnamomi inoculum. The protective effect of the symbiosis can also change with the AMF. BÄRTSCHI et al. (1981) showed that it was more interesting to inoculate with a mixture of symbiotic fungi to ensure good plant growth and a good level of tolerance towards the pathogen. Such a mixture could contain efficient fungi for both mineral nutrition and protection, and so act synergistically to provide more efficient tolerance to the pathogen.

It is well known that AMF positively influence $\mathrm{P}$ nutrition of plants (HARLEY and SMITH 1983) and increases in P nutrition have been suggested to decrease root membrane permeability, therefore reducing and modifying root exudation (RATNAYAKE et al. 1978). Root exudates of endomycorrhizal plants have been reported to contain more arginine and reducing sugars (BALTRUSCHAT and SCHÖNBECK 1975), and changes in exudate composition can modify rhizosphere populations and decrease pathogen activity (GRAHAM and Menge 1982). Meyer and Linderman (1986) reported reductions in sporangia and zoospore production by $P$. cinnamomi in rhizosphere soil extracts from endomycorrhizal roots. Better absorption of $\mathrm{P}$ by endomycorrhizal roots could also counterbalance pathogen damage (DAVIS and MENGE 1980), but $\mathrm{P}$ is probably not the only factor contributing to pathogen tolerance (GRAHAM and EGEL 1988). The present study on pineapple shows that the influence of $P$. cinnamomi also depends on the age of the two varieties at the time of pathogen inoculation and that this is modified by endomycorrhiza infection. Non-mycorrhizal plants were more severely affected by early inoculation with the pathogen but no such difference was observed with endomycorrhiza formation, indicating modifications in the physiology of the plant. Endomycorrhiza can influence other aspects of plant physiology than mineral nutrition. As could be expected, they modified biomass distribution in pineapple, root production being lower in relation to that of shoots. However, the application of the highest inoculum level of $P$. cinnamomi inversed this proportion for Queen Tahiti variety, suggesting that the endomycorrhizal plants may have produced a more important root system to support the pathogen. AMF can also influence phenol metabolism and root lignification (DEHNE and SCHÖNBECK 1979), making plants better adapted to resist to pathogen aggressions.

Other micro-organisms can show a potential for biological control of Phytophthora root rot, such as antagonistic bacteria and fungi (BROADBENT and BAKER 1974, GEes and COFFEY 1989, OwNLEY and BENSON 1992). CALVET et al. (1993) have reported the synergistic action of a fungal antagonist with an AMF in increasing marigold growth in the presence of Pythium ultimum. This effect may be through increases in the population of the antagonistic micro-organism under the influence of AMF (SECILIA and Bagyaraj 1987), and opens the possibility of using both groups of mycoflora for improving biocontrol of the root pathogen.

\section{Conclusion}

AMF can be considered as potential biological control agents contributing to tolerance to $P$. cinnamomi in pineapple; the Smooth Cayenne variety may be more tolerant to $P$. cinnamomi aggression. It will be interesting to use this biotechnology in association with other antagonists, or with reasonable pesticide applications (AzIZ et al. 1990, Guillemin et al. 1993), when pathogen pressure is very important. Futhermore, introduction of endomycorrhization during early stages of pineapple plant production represents an interesting technology towards improving plant development with decreases in chemical input.

Acknowledgements. The authors thank Vitropic S.A. (Montpellier, France) for supplying the micropropagated plant material and Dr Mourichon X. (CIRAD, FLHOR, Montpellier, France) for Phytophthora cinnamomi Rands. 


\section{References}

Anderson, E.J. 1951. The Phytophthora cinnamomi problem in pineapple fields of Hawaii. Phytopathology 41: 187-188.

AzIz, T., Yuen J.E. \& HabTe M. 1990. Response of pineapple to mycorrhizal inoculation and fosetyl-Al treatment. Communication in Soil Science and Plant Analysis 21: 2309-2317.

Baltruschat, H. \& Schönbeck, F. 1975. The influence of endotrophic mycorrhiza on the infestation of tobacco by Thielaviopsis basicola. Phytopathologische Zeitschrift 84: 172-188.

Bärtschi, H., Gianinazzi-Pearson, V. \& Vegh, I. 1981. Vesicular-arbuscular mycorrhiza formation and root rot disease (Phytophthora cinnamomi) development in Chamaecyparis lawsoniana. Phytopathologische Zeitschrift 102: 213-218.

BRoAdBENT, P. \& BAKER, K.F. 1974. Association of bacteria with sporangium formation and breakdown of sporangia in Phytophthora spp.. Australian Journal of Agricultural Research 25: 139-145.

Calvet, C., Pera, J. \& Barea, J.M. 1993. Growth response of marigold (Tagetes erecta L.) to inoculation with Glomus mosseae, Trichoderma aureoviride and Pythium ultimum in a peat-perlite mixture. Plant and Soil 148: 1-6.

Chauvel, B. 1991. Polymorphisme génétique et sélection de la résistance aux urées substituées chez Alopecurus myosuroïdes Huds. Thesis of University, Paris-Sud, Orsay. $160 \mathrm{p}$.

Comité Inter Instituts pour le diagnostic foliaire 1968. Méthode de référence pour la détermination des éléments minéraux dans les végétaux. Coll. Eur. Méd. sur le contrôle de l'alimentation des Plantes cultivées, Seville. p. 12-20.

- 1972. Méthode de référence pour la détermination des éléments minéraux dans les végétaux. Coll. Eur. Méd. sur le contrôle de l'alimentation des Plantes cultivées, Budapest. p. 144-150.

Davis, R.M., Menge, J.A. \& Zentmyer, G.A. 1978. Influence of vesicular-arbuscular mycorrhizae on Phytophthora root rot of three crop plants. Phytopathology 68 : 1614-1617.

- \& MENGE, J.A. 1980. Influence of Glomus fasciculatus and soil phosphorus on Phytophthora root rot of citrus. Phytopathology $70: 447-452$.

- \& Menge, J.A. 1981. Phytophthora parasitica inoculation and intensity of vesicular-arbuscular mycorrhizae in citrus. New Phytologist 87: 705-715.

DEHNE, H.W. \& SCHÖNBECK, F. 1979. The influence of endotrophic mycorrhiza on plant diseases. II. Phenol metabolism and lignification. Phytopathologische Zeitschrift 95: 210-216.

GeEs, R. \& COFFEY, M.D. 1989. Evaluation of a strain of Myrothecium roridum as a potential biocontrol agent against Phytophthora cinnamomi. Phytopathology 79: 1079-1084.
Gianinazzi, S., Gianinazzi-Pearson, V. \& Trouvelot, A. 1982. Les Mycorhizes, Partie Intégrante de la Plante : Biologie et Perspective d'Utilisation. INRA Press, Paris, France. 397 p.

Graham, J.H. \& EgEL, D.S. 1988. Phytophthora root rot development on mycorrhizal and phosphorus-fertilized nonmycorrhizal sweet orange seedlings. Plant Disease 72: 611-614.

- \& MENGE, J.A. 1982. Influence of vesicular-arbuscular mycorrhizae and soil phosphorus on take-all disease of wheat. Phytopathology 72: 95-98.

Guillemin, J.P., Gianinazzi, S. \& Gianinazzi-Pearson, V. 1991. L'endomycorhization de vitroplants d'Ananas comosus : mise en évidence d'un effet mycorhizien. Fruits 46: $355-358$.

-, Abdel-Fattah, G.M., Trouvelot, A., Gianinazzi, S. \& GIANINAZZI-PEARSON, V. 1993. Interactions between soil-applied fungicides, endomycorrhiza fungal activity and plant growth. Trends in Agricultural Sciences. Soil Science 1: 161-172.

HaRley, J.L. \& SMITH, S.E. 1983. Mycorrhizal Symbiosis. Academic Press, Inc., London-New York. 483 p.

Hoagland, D.R. \& ARNON, D.I. 1950. The water-culture method for growing plants without soil. California Agricultural Experiment Station Circular 347: 1-32.

LOUVEL, D. 1975. Etude des relations entre l'ananas et le Phytophthora parasitica: mise au point d'une technique d'inoculation, localisation des niveaux de la résistance. Fruits 30: 669-679.

Mataré, R. \& Hatting, M.J. 1978. Effect of mycorrhizal status of avocado seedlings on root rot caused by Phytophthora cinnamomi. Plant and Soil 49: 433-435.

Menrlich, F.P. 1934. Control of Phytophthora heart rot of pineapple plants. Phytopathology 24: 173-196.

- 1936. Pathogenicity and variation in Phytophthora species causing heart rot of pineapple plants. Phytopathology 26: 23-43.

Meyer, J.R. \& Linderman, R.G. 1986. Selective influence on population of rhizosphere or rhizoplane bacteria and actinomycetes by mycorrhizas formed by Glomus fasciculatum. Soil Biology and Biochemistry 18: 191-196.

Ownley, B.H. \& Benson, D.M. 1992. Evaluation of Penicillium janthinellum as a biological control of Phy. tophthora root rot of azalea. Journal of the American Society for Horticultural Science 117: 407-410.

Paulitz, T.C. \& Linderman, R.G. 1991. Mycorrhizal interactions with soil organisms. In: Arora, D.K. et al. (eds). Handbook of Applied Mycology. Marcel Dekker, Inc., New York, Basel, Hong Kong. p. 77-129.

PEGG, K.G. 1977. Soil application of element sulphur as a control of Phytophthora cinnamomi root and heart rot of pineapple. Australian Journal of Experimental Agriculture and Animal Husbandry 17: 859-865.

PHILIPPS, J.M. \& HAYMAN, D.S. 1970. Improved procedures for clearing roots and staining parasitic and ve- 
sicular-arbuscular mycorrhizal fungi for rapid assessment of infection. Transactions of the British Mycological Society 55: 158-161.

Py, C., Lacoeuilhe, J.J. \& Teisson, C. 1984. L'ananas: sa culture, ses produits. G.P. Maisonneuve \& Larose, Paris $\left(\mathrm{V}^{\circ}\right) .562 \mathrm{p}$.

Ratnayake, M., Leonard, R.T. \& Menge, J.A. 1978. Root exudation in relation to supply of phosphorus and its possible relevance to mycorrhizal formation. New Phytologist 81: 543-552.

RochBACH, K.G. \& SCHENCK, S. 1985. Control of pineapple heart rot, caused by Phytophthora parasitica and $P$. cinnamomi, with metalaxyl, fosetyl-Al, and phosphorous acid. Plant Disease 69: 320-323.

Secilia, J. \& BagyaraJ, D.J. 1987. Bacterial and actinomycetes with pot cultures of vesicular-arbuscular mycorrhizas. Canadian Journal of Microbiology 33: 10691073.

Smith, S.E. \& Gianinazzi-Pearson, V. 1990. Phosphate uptake and vesicular-arbuscular activity in mycorrhizal Allium cepa L.: effect of photon irradiance and phos- phate nutrition. Australian Journal of Plant Physiology 17: $177-188$.

Tisserant, B., Gianinazzi-Pearson, V., Gianinazzi, S. \& Gollote, A. 1993. In planta histochemical staining of fungal alkaline phosphatase activity for analysis of efficient arbuscular endomycorrhizal infections. Mycological Research 97: 245-250.

Trouvelot, A., Kough, J. \& Gianinazzi-Pearson, V. 1986. Mesure du taux de mycorhization VA d'un système radiculaire. Recherche de méthodes d'estimation ayant une signification fonctionnelle. In: Gianinazzi-Pearson, V. \& Gianinazzi, S. (eds.). Physiological and Genetical Aspects of Mycorrhizae. INRA Press, Paris. p. 217-221.

WARNER, M.H. \& JoNES, J.B. 1967. Determination of total tissue using a Technicon Kjeldahl Nitrogen apparatus. Technicon Symposia 1966, Automation in analytical chemistry, Vol. I. Mediad Inc., New York. p. 145148.

Manuscript received December 1993

\title{
SELOSTUS
}

\section{Mykorritsasienten merkitys biologisena torjuntakeinona Phytophthora cinnamomi -tautia vastaan mikrolisätyllä ananaksella (Ananas comosus (L.) Merr).}

\author{
Jean-Philippe Guillemin ${ }^{1}$, Silvio Gianinazzi ${ }^{1}$, Vivienne Gianinazzi-Pearson ${ }^{1}$ ja Jean Marchal ${ }^{2}$ \\ ' Laboratoire de Phytoparasitologie, INRA-CNRS, Dijon, Ranska ja ${ }^{2}$ Laboratoire de Physiologie et Biochimie, \\ CIRAD, FLHOR, Montpellier, Ranska
}

Phytophthora cinnamomi Rands aiheuttaa ananaksessa satoa alentavaa juurilahoa. Tutkimuksessa selvitettiin arbuskelimykorritsasienisiirrostuksen vaikutusta $P$. cinnamomisientä vastaan ananaslajikkeilla Queen Tahiti ja Smooth Cayenne. Mykorritsasieni siirrostettiin ananaksen pikkutaimiin in vitro -vaiheen jälkeen. Erisuuruiset $P$. cinnamo$m i$-tartutemäärät eivät vaikuttaneet mykorritsallisten kasvien kasvuun ja ravinteiden ottoon, mutta mykorritsattomilla kasveilla $P$. cinnamomi alensi sekä kasvua että ra- vinteiden ottoa. Mykorritsallisten kasvien juuri/verso -suhde oli pienempi kuin mykorritsattomien kasvien eikä $P$. cinnamomi vaikuttanut suhteeseen muulloin kuin käytettäessä suurimpia tartutemääriä. Taudinaiheuttajan vaikutus juurten mykorritsasieni-infektioon oli vähäinen, mutta symbioosin toiminta heikkeni suurimmilla $P$. cinnamomiin tartutemäärillä. Mykorritsasienten hyödyntäminen on mielenkiintoinen bioteknologian sovellutus mikrolisättyjen ananastaimien tuotannossa. 